\title{
PERILAKU KONSUMEN DALAM PEMBELIAN BAKSO DI MALANG
}

\section{THE CONSUMERS`BEHAVIOR IN PURCHASING MEATBALLS IN MALANG}

\author{
Budi Hartono*, Umi Wisapti Ningsih, dan Nila Fithria Septiarini \\ Fakultas Peternakan, Universitas Brawijaya, Jl. Veteran, Malang, Jawa Timur
}

\begin{abstract}
INTISARI
Penelitian dilaksanakan dengan tujuan untuk mengetahui karakteristik dan faktor yang mempengaruhi pembelian bakso sapi di Malang. Penelitian dilakukan di Malang, Jawa Timur pada bulan Maret 2011. Jumlah responden sebanyak 120 konsumen yang dipilih secara Accidental Sampling. Data dianalisis dengan cara deskriptif dan analisis faktor. Hasil penelitian menunjukkan bahwa sebagian besar responden melakukan pembelian bakso adalah perempuan, berstatus pelajar, mempunyai umur di bawah 35 tahun, pendapatan individu yang diperoleh antara Rp. 1.000.000,00 sampai Rp. 2.000.000,00 per bulan dan harga bakso dikategorikan terjangkau oleh konsumen. Pola mengkonsumsi bakso bukan sebagai makanan pokok tetapi sebagai kuliner, hobi, dan makanan camilan. Delapan faktor yang dipertimbangkan responden secara berurutan adalah harga, kelas sosial, kemudahan mencapai lokasi, parkir, tampilan penyajian, kepuasan, pendapatan, dan demografi.
\end{abstract}

(Kata kunci: Perilaku konsumen, Faktor yang dipertimbangkan, Bakso)

\section{ABSTRACT}

The objective of this research were to analyzed the characteristics and the factors influencing the purchasing of meatballs in Malang. The research was conducted in Malang, East Java in March 2011. One hundred and twenty consumers were chosen as respondents by Accidental Sampling method. Data were analyzed by descriptive and factor analyses. The results showed that most customers were women, student status, with the age below 35 years old, and incomes level of IDR 1.000.000,00 into IDR 2.000.000,00 per month. The meatball's price was affordable by the consumers. The meatball's purchasing patterns showed that the meatball was consumed not as a main meal but only for culinary, hobby and also as snacks. The eight factors considered by consumers of meatball purchasing consecutively were price, social class, accessibility, parking, display presentation, satisfaction, income and demographics, respectively.

(Key words: Consumer`s behavior, Considerance factor, Meatball)

\section{Pendahuluan}

Kota Malang juga dikenal sebagai kota Bakso selain kota Apel. Bakso merupakan makanan daging sapi yang dicampur dengan terigu yang dimasak dengan proses tertentu untuk dikonsumsi. Bakso sangat populer dan digemari semua kalangan dengan harga yang bervariasi dan terjangkau oleh konsumen. Tarwotjo et al. (1971) menjelaskan bahwa bakso daging sapi merupakan sumber protein hewani karena daging sapi mengandung protein yang sangat dibutuhkan oleh tubuh manusia. Usaha bakso membutuhkan tenaga kerja mulai dari lokasi penggilingan, sampai daerah produsen dan pemasaran. Bakso dibuat menggunakan daging segar agar dihasilkan bakso yang kenyal dan kompak. Bahan baku bakso umumnya berasal dari daging

\footnotetext{
* Korespondensi (corresponding author):

Telp. +62 8156895246

E-mail: budihartono_ub@yahoo.com
}

paha belakang sapi, akan tetapi dapat juga dibuat dari bagian karkas lainnya.

Usaha bakso dapat digolongkan sebagai usaha kecil. Parubak et al. (2004) menjelaskan bahwa usaha kecil mempunyai peranan penting dan strategis dalam mewujudkan pembangunan nasional. Usaha kecil merupakan usaha yang ditekuni oleh sebagian besar masyarakat dan merupakan usaha yang mampu memperluas lapangan kerja dan memberikan pelayanan yang luas kepada masyarakat. Pemerintah terus berupaya membina kelompok usaha kecil agar menjadi usaha yang semakin efisien dan mampu berkembang mandiri dan dapat membuka lapangan kerja baru.

Dua faktor yang mempengaruhi pengambilan keputusan konsumen dalam melakukan pembelian yaitu faktor internal dan faktor eksternal (Asseal, 1992). Faktor eksternal terdiri dari faktor 
lingkungan dan strategi bauran pemasaran. Faktor lingkungan terdiri dari faktor budaya, referensi dan kelas sosial. Strategi bauran pemasaran terdiri dari produk, harga, promosi, dan distribusi. Faktor internal terdiri dari faktor gagasan dan karakteristik konsumen. Faktor internal dan eksternal dalam interaksinya dapat mempengaruhi perilaku konsumen baik secara individual maupun secara bersama-sama.

Konsumen melakukan pembelian tidak terlepas dari karakteristik produk baik mengenai penampilan, gaya, mutu dan harga dari produk tersebut. Penetapan harga oleh penjual akan berpengaruh terhadap perilaku pembelian konsumen, sebab harga yang dapat dijangkau oleh konsumen akan cenderung membuat konsumen melakukan pembelian terhadap produk tersebut. Karakteristik penjualan bakso akan mempengaruhi keputusan membeli. Konsumen akan menilai mengenai penjual, baik mengenai pelayanan, mudahnya memperoleh produk dan sikap ramah dari penjual (Tedjakusuma et al., 2001).

Penjual bakso harus memahami keinginan konsumen dengan cara mempelajari perilaku konsumen agar konsumen bersedia membeli baksonya. Pemahaman perilaku konsumen yang baik dan tepat diharapkan akan mengembangkan kegiatan pemasarannya. Penjual bakso daging perlu mengenal konsumen, sasaran dan model keputusan yang dilakukan oleh konsumen, sehingga penjual bakso daging mengetahui motif konsumen dalam menilai bakso daging yang sesuai dengan hati nuraninya. Analisis faktor digunakan untuk menentukan urutan faktor yang dipertimbangkan oleh konsumen dalam membeli bakso daging di Kota Malang, sehingga perlu dilakukan penelitian agar penjual bakso dapat mempertahankan eksistensinya.

\section{Materi dan Metode}

Penelitian dilakukan dengan metode survei di Kota Malang dengan pertimbangan bahwa Kota Malang dikenal sebagai Kota Bakso. Pengambilan data dilaksanakan pada bulan Maret 2011 di lima lokasi terbesar yang diambil secara purposive sampling yaitu Bakso Solo Kidul Pasar, Bakso Kota Cak Man, Bakso Bakar Pahlawan Trip, Bakso Presiden dan Bakso Duro Kepanjen. Jumlah sampel sebanyak 120 responden yang diambil secara Accidental Sampling. Pengumpulan data primer dengan melakukan tanya jawab dengan responden berdasarkan kuesioner yang telah dipersiapkan.

Analisis statistik deskriptif digunakan untuk mendiskripsikan karakteristik responden yang diteliti serta distribusi item dari tiap variabel dalam angka persentase. Analisis faktor digunakan untuk menentukan urutan faktor yang dipertimbangkan oleh konsumen dalam membeli bakso. Jenis data yang digunakan analisis faktor adalah data ordinal dan skala pengukuran yang digunakan adalah skala Likert.

\section{Hasil dan Pembahasan}

\section{Gambaran umum responden}

Hasil survei menunjukkan bahwa usia konsumen yang mendominasi adalah kelompok usia 16-25 tahun sebanyak 62,5\% dan usia 26-35 tahun sebanyak 25,83\% (Tabel 1). Kelompok usia ini tergolong usia produktif sehingga memerlukan kandungan nutrisi yang cukup bagi tubuh dan perlunya menjaga kesehatan. Konsumen pada usia muda (remaja) dipengaruhi oleh aktifitas yang ditekuninya, teman-teman, dan penampilan dari generasi tersebut. Usia responden diatas 45 tahun lebih sedikit dikarenakan pada usia ini seseorang lebih berhati-hati dalam memilih dan mengkonsumsi makanan yaitu lebih memilih makanan yang terbuat dari sayur-mayur (Kasali, 1998 cit. Hermanianto dan Andayani, 2002).

Hasil survei menunjukkan (Tabel 2) bahwa responden perempuan $(53,33 \%)$ lebih banyak dijumpai dibanding laki-laki (46,67\%) karena perempuan mempunyai kecenderungan senang berkumpul dan sering secara bersama-sama membeli atau jajan bakso dengan tidak direncanakan. Hasil penelitian ini tidak jauh berbeda dengan hasil penelitian Hermanianto dan Andayani (2002) yang menjelaskan bahwa pembeli bakso lebih didominasi kaum perempuan karena perempuan mempunyai kecenderungan lebih senang berbelanja, mudah terpengaruh oleh emosi dan menyukai jajan atau ngemil. Alasan ini yang melatarbelakangi wanita sebagai konsumen terbesar bakso sapi.

Tabel 1. Karakteristik responden berdasarkan usia (characteristics of respondents by the age)

\begin{tabular}{cc}
\hline \hline Usia (tahun) (age (years)) & Persentase (percentage) \\
\hline $16-25$ & 62,50 \\
$26-35$ & 25,83 \\
$36-45$ & 9,17 \\
$46-55$ & 1,67 \\
$56-65$ & 0,83 \\
\hline Jumlah (total) & 100,00 \\
\hline
\end{tabular}

Tabel 2. Karakteristik responden berdasarkan jenis kelamin (characteristics of respondents by sex)

\begin{tabular}{cc}
\hline \hline Jenis kelamin $($ sex $)$ & Persentase (percentage) \\
\hline Laki-laki (male) & 46,67 \\
Perempuan (female) & 53,33 \\
\hline Jumlah $($ total $)$ & 100,00 \\
\hline
\end{tabular}


Kelompok sasaran berdasarkan pendidikan yang ditempuh konsumen menunjukkan bahwa sebanyak $44,17 \%$ responden memiliki pendidikan akhir SMU dan 39,17\% responden memiliki pendidikan akhir sarjana (Tabel 3), sehingga sebagian besar konsumen adalah berpendidikan tinggi dan terpelajar. Pendidikan sebagai faktor psikologis yang berpengaruh terhadap jenis dan mutu bahan makanan yang akan dikonsumsi. Hal ini memperlihatkan bahwa tingkat pemahaman dan pengetahuan seseorang tentang pentingnya kandungan gizi dipengaruhi oleh tingkat pendidikan (Kasali, 1998 cit. Hermanianto dan Andayani, 2002).

Data berdasarkan alasan konsumen membeli bakso menunjukkan bahwa mayoritas konsumen mengkonsumsi bakso karena bukan sebagai makanan utama $(3,33 \%)$ tetapi sebagai kuliner, hobi, makanan camilan (Tabel 4). Konsumen membeli bakso kuah umumnya dicampur dengan makanan lain seperti gorengan, tahu atau sedikit mie basah. Responden membeli bakso biasanya di tempat terkenal dan memiliki rasa yang sesuai dengan selera konsumen.

Produk bakso tetap digemari oleh konsumen. Karakteristik utama responden dalam membeli bakso adalah daya beli konsumen yang dapat diperhatikan dari penghasilan yang diperoleh konsumen setiap bulan. Kebanyakan konsumen membeli bakso selain memperhatikan harga juga memperhatikan cara penyajian yang cepat dan praktis. Rerata harga

Tabel 3. Karakteristik responden berdasarkan pendidikan (characteristics of respondents by education)

\begin{tabular}{lc}
\hline \hline \multicolumn{1}{c}{ Pendidikan (education) } & $\begin{array}{c}\text { Persentase } \\
\text { (percentage) }\end{array}$ \\
\hline SD/Sederajat (elementary school) & 0,83 \\
SMP/Sederajat (junior high school) & 5,83 \\
SMU/Sederajat (senior high school) & 44,17 \\
Akademi/Sederajat (academy) & 10,00 \\
Sarjana (under/graduate school) & 39,17 \\
\hline \multicolumn{1}{c}{ Jumlah (total) } & 100,00 \\
\hline
\end{tabular}

Tabel 4. Karakteristik responden berdasarkan alasan mengkonsumsi bakso (characteristics of respondents by reasons consuming meatballs)

\begin{tabular}{cc}
\hline \hline $\begin{array}{c}\text { Alasan mengkonsumsi bakso } \\
\text { (reason consuming meatballs) }\end{array}$ & $\begin{array}{c}\text { Persentase } \\
\text { (percentage) }\end{array}$ \\
\hline Makanan utama (the main food) & 3,33 \\
Makanan camilan (snack foods) & 31,67 \\
Hobi (hobby) & 31,67 \\
Kuliner (culinary) & 33,33 \\
\hline \multicolumn{1}{c}{ Jumlah (total) } & 100,00 \\
\hline
\end{tabular}

bakso satu porsi di Malang Rp. 5.000,00. Hasil survei menunjukkan bahwa harga satu porsi bakso tersebut adalah sedang (Tabel 5) atau cukup yang berarti tidak terlalu mahal ataupun tidak terlalu murah, sedangkan bakso tersebut dianggap konsumen bukan sebagai makanan utama.

\section{Analisis faktor}

Hasil analisis faktor perilaku konsumen dalam pembelian bakso di Malang menghasilkan 8 faktor yang terbentuk (Tabel 7). Tabel 7 memperlihatkan bahwa faktor-faktor yang terbentuk merupakan faktor yang dipertimbangkan konsumen dalam pembelian bakso di Malang sebesar 63,76\% dan sisanya sebesar $37,14 \%$ merupakan faktorfaktor yang tidak terlalu dipertimbangkan oleh konsumen. Untuk lebih jelasnya akan dibahas interpretasi tiap faktor dari kedelapan faktor yang terbentuk (Tabel 7).

Faktor persepsi konsumen merupakan salah satu faktor yang mempengaruhi perilaku konsumen dalam membeli produk bakso daging sapi memiliki persentase varian sebesar $16,69 \%$ dan merupakan urutan pertama yang dipertimbangkan oleh konsumen karena mempunyai nilai Eigen Value terbesar yaitu 3,672. Variabel yang memiliki factor loading terbesar pada persepsi konsumen adalah variabel harga yaitu sebesar 0,717 yang artinya variabel harga memiliki korelasi sangat kuat terhadap faktor persepsi konsumen. Responden

Tabel 5. Karakteristik responden berdasarkan harga (characteristics of respondents by price)

\begin{tabular}{lc}
\hline \multicolumn{1}{c}{ Harga (price) } & $\begin{array}{c}\text { Persentase } \\
\text { (percentage) }\end{array}$ \\
\hline Sangat mahal (very expensive) & 3,33 \\
Mahal (expensive) & 13,33 \\
Sedang (medium) & 57,50 \\
Murah (cheap) & 19,17 \\
Sangat murah (very cheap) & 6,67 \\
\hline \multicolumn{1}{c}{ Jumlah (total) } & 100,00 \\
\hline
\end{tabular}

Tabel 6. Karakteristik responden berdasarkan pendapatan (characteristics of respondents by income)

\begin{tabular}{|c|c|}
\hline Pendapatan (Rp) (income $(R p))$ & $\begin{array}{c}\text { Persentase } \\
\text { (percentage) }\end{array}$ \\
\hline$<500.000$ & 21,67 \\
\hline $500.000-1.000 .000$ & 13,33 \\
\hline $1.000 .001-1.500 .000$ & 28,33 \\
\hline $1.500 .001-2.000 .000$ & 24,17 \\
\hline$>2.000 .000$ & 12,50 \\
\hline Jumlah (total) & 100,00 \\
\hline
\end{tabular}


Tabel 7. Analisis faktor perilaku konsumen dalam pembelian bakso (factor analysis of consumer behavior in purchasing meatballs)

\begin{tabular}{|c|c|c|c|c|}
\hline Faktor (factor) & Variabel (variable) & Eigen value & Loading factor & $\%$ \\
\hline $\begin{array}{l}\text { Persepsi konsumen } \\
\text { (consumer perception) }\end{array}$ & $\begin{array}{l}\text {-Kepercayaan (confidence) } \\
\text {-Produk terkenal (famous products) } \\
\text {-Ukuran produk (size of product) } \\
\text {-Harga (price) }\end{array}$ & 3,672 & $\begin{array}{l}0,429 \\
0,551 \\
0,675 \\
0,717\end{array}$ & 16,69 \\
\hline $\begin{array}{l}\text { Lingkungan } \\
\text { (environment) }\end{array}$ & $\begin{array}{l}\text {-Kebudayaan (culture) } \\
\text {-Kelas sosial (social class) } \\
\text {-Kelompok sosial (social groups) }\end{array}$ & 2,048 & $\begin{array}{l}0,680 \\
0,741 \\
0,729\end{array}$ & 9,31 \\
\hline Referensi (reference) & $\begin{array}{l}\text {-Pengetahuan (knowledge) } \\
\text {-Faktor promosi (promoting factor) } \\
\text {-Kemudahan mencapai lokasi (ease of reaching } \\
\text { the location) }\end{array}$ & 1,915 & $\begin{array}{l}0,577 \\
0,623 \\
0,814\end{array}$ & 8,71 \\
\hline $\begin{array}{l}\text { Kepedulian produsen } \\
\text { (concern manufacturer) }\end{array}$ & $\begin{array}{l}\text {-Kenyamanan (convenience) } \\
\text {-Tempat parkir (the parking lot) } \\
\text {-Kebersihan tempat (hygiene place) } \\
\text {-Pelayanan produsen (producer service) }\end{array}$ & 1,529 & $\begin{array}{l}0,486 \\
0,780 \\
0,758 \\
0,482\end{array}$ & 6,95 \\
\hline $\begin{array}{l}\text { Karakteristik produk } \\
\text { (characteristics of } \\
\text { product) }\end{array}$ & $\begin{array}{l}\text {-Tampilan penyajian (view presentation) } \\
\text {-Rasa dan tekstur (the taste and texture) }\end{array}$ & 1,526 & $\begin{array}{l}0,924 \\
0,609\end{array}$ & 6,94 \\
\hline Pengalaman (experience) & $\begin{array}{l}\text {-Kepuasan sebelumnya (previous satisfaction) } \\
\text {-Hobi (hobbies) }\end{array}$ & 1,246 & $\begin{array}{l}0,798 \\
0,588\end{array}$ & 5,66 \\
\hline $\begin{array}{l}\text { Kepuasan konsumen } \\
\text { (consumer satisfaction) }\end{array}$ & $\begin{array}{l}\text {-Pendapatan (revenue) } \\
\text {-Kepribadian (personality) }\end{array}$ & 1,054 & $\begin{array}{l}0,748 \\
0,716\end{array}$ & 4,79 \\
\hline $\begin{array}{l}\text { Karakteristik konsumen } \\
\text { (characteristics of } \\
\text { consumers) }\end{array}$ & -Demografi (demographics) & 1,036 & 0,767 & 4,71 \\
\hline
\end{tabular}

mempertimbangkan harga bakso karena menurut penilaian responden tingkat harga akan mempengaruhi jumlah pembelian suatu produk yang akan dikonsumsi. Hal tersebut diperkuat dengan penilaian harga tidak terlalu mahal untuk setiap porsi bakso adalah Rp. 5.000,00 yang termasuk kategori sedang $(57,5 \%)$ (Tabel 5), sehingga apabila harga bakso terlalu tinggi maka responden akan mempertimbangkan ulang sebelum membeli produk tersebut.

Faktor lingkungan memiliki persentase varian sebesar 9,310\% dan memiliki urutan kedua faktor yang dipertimbangkan oleh konsumen dengan nilai Eigen Value terbesar yaitu 2,048. Variabel yang memiliki factor loading terbesar pada faktor lingkungan adalah variabel kelas sosial sebesar 0,741 yang artinya bahwa variabel kelas sosial memiliki korelasi kuat terhadap faktor lingkungan, sedangkan variabel yang memiliki factor loading terkecil adalah variabel kebudayaan sebesar 0,680 yang artinya bahwa variabel kebudayaan memiliki korelasi paling lemah jika dibandingkan dengan kedua variabel lain yang mendukung pada faktor lingkungan.
Kebudayaan tidak terlalu dipertimbangkan oleh responden, dikarenakan responden membeli produk bakso bukan karena adat atau kebiasaan masyarakat tertentu untuk mengkonsumsi produk ini. Produk ini bukan menjadi makanan utama bagi responden. Hal ini diperkuat dengan penilaian responden bahwa produk bakso bukan menjadi makanan utama hanya 3,33\% (Tabel 5). Produk ini dikonsumsi hanya sebagai kuliner, hobi, dan makanan camilan.

Kelas sosial responden mempertimbangkan untuk membeli produk bakso tersebut. Tingkat penghasilan responden sangat berpengaruh terhadap pembelian produk bakso. Penghasilan yang lebih akan mempengaruhi kemudahan responden untuk membeli produk tersebut. Hal ini diperkuat dengan data responden yang memiliki penghasilan Rp. $1.000 .000,00$ - Rp. 2.000.000,00 sebanyak $52,50 \%$ (Tabel 6) akan membeli produk tersebut lebih mudah karena menganggap produk tersebut memiliki harga yang relatif terjangkau.

Faktor referensi memiliki persentase varians sebesar $8,707 \%$ merupakan faktor urutan ketiga yang dipertimbangkan oleh konsumen dengan nilai 
Eigen Value terbesar yaitu 1,915. Variabel yang memiliki factor loading terbesar adalah variabel kemudahan mencapai lokasi sebesar 0,814 yang artinya bahwa variabel kemudahan mencapai lokasi memiliki korelasi kuat terhadap faktor referensi.

Faktor yang menyebabkan perilaku pembelian seseorang bisa juga dipengaruhi oleh referensi kelompok. Referensi kelompok adalah kelompok sosial yang menjadi ukuran seseorang (bukan anggota kelompok tersebut) untuk membentuk kepribadian dan perilakunya (Sudarmiatin, 2009). Tingkat pengetahuan yang kurang pada responden terhadap lokasi-lokasi pemasaran produk bakso menjadi pertimbangan konsumen untuk menerima pendapat atau masukan-masukan yang diberikan oleh orang-orang disekitar responden. Faktor promosi disini sangat berpengaruh terhadap keputusan pembelian produk tersebut oleh responden. Faktor promosi salah satunya yaitu tentang kemudahan mencapai lokasi produk tersebut dipasarkan. Kemudahan mencapai lokasi tersebut sangat dipertimbangkan responden untuk membeli produk tersebut, karena apabila lokasi tersebut sulit dijangkau maka responden akan memilih lokasi yang lainnya.

Faktor kepedulian produsen memiliki persentase varians sebesar $6,951 \%$ dan memiliki urutan keempat faktor yang dipertimbangkan oleh konsumen dengan nilai Eigen Value terbesar yaitu 1,529. Variabel yang memiliki factor loading terbesar adalah variabel tempat parkir sebesar 0,780 yang artinya bahwa variabel tempat parkir memiliki korelasi kuat terhadap faktor kepedulian produsen.

Tempat parkir pada lokasi penjualan produk sangat dipertimbangkan oleh responden, karena konsumen akan lebih merasa nyaman jika pada saat menikmati bakso, kendaraan yang diparkir terletak pada tempat yang aman dan diawasi oleh petugas parkir. Sulistyawati (2004), menyatakan bahwa tersedianya sarana parkir yang memadai dan aman merupakan faktor yang mempengaruhi konsumen dalam pembelian suatu produk, karena hal ini dapat memberikan keamanan dan kenyamanan terutama dari gangguan pengamen, pedagang asongan dan pengemis.

Kebersihan tempat juga dipertimbangkan oleh responden, karena lokasi yang bersih, sarana dan prasarana yang bersih, serta sirkulasi udara yang lancar akan menambah nafsu makan responden. Kebersihan tempat merupakan salah satu yang harus diperhatikan oleh pemilik usaha produk tersebut dikarenakan apabila tempat penyajian produk tidak bersih akan menyebabkan penyebaran penyakit yang ditularkan oleh konsumen kepada konsumen yang lainnya.

Faktor karakteristik produk memiliki persentase varian sebesar $6,938 \%$. Variabel tampilan pe- nyajian memiliki factor loading terbesar 0,924 bahwa variabel tampilan penyajian memiliki korelasi kuat terhadap faktor karakteristik produk.

Tampilan penyajian suatu produk sangat dipertimbangkan oleh responden dalam membeli bakso daging sapi. Penyajian produk yang diberikan pada responden kurang menarik akan mengurangi selera makan responden begitu juga sebaliknya jika penyajian produk terlihat menarik maka responden akan bertambah selera makan. Tampilan penyajian suatu produk sangat berkaitan dengan rasa dan tekstur produk yang disajikan.

Faktor pengalaman memiliki persentase varian sebesar $5,663 \%$. Variabel yang memiliki factor loading terbesar adalah variabel kepuasan sebelumnya sebesar 0,798 yang artinya bahwa variabel kepuasan sebelumnya memiliki korelasi kuat terhadap faktor pengalaman.

Kepuasan pembelian produk sebelumnya merupakan salah satu hal yang sangat dipertimbangkan oleh responden dalam pembelian produk tersebut. Hal ini dikarenakan pengalaman pembelian produk sebelumnya akan menjadi kesan tersendiri bagi para responden. Apabila responden merasa puas pada saat membeli produk sebelumnya maka responden akan membeli produk tersebut kembali. Selain itu hobi merupakan suatu hal yang berpengaruh terhadap responden dalam pembelian produk tersebut karena produk bakso daging sapi merupakan makanan yang banyak digemari oleh berbagai kalangan masyarakat sehingga banyak responden yang membeli produk tersebut karena kesenangan atau hobi mengkonsumsi produk tersebut.

Faktor kepuasan konsumen memiliki persentase varian sebesar $4,790 \%$. Variabel yang memiliki factor loading terbesar adalah variabel pendapatan sebesar 0,748 yang artinya bahwa variabel ini memiliki korelasi kuat terhadap faktor kepuasan konsumen.

Pendapatan berkaitan dalam mempertimbangkan pembelian produk bakso. Responden yang memiliki pendapatan lebih banyak cenderung memiliki kepribadian yang boros atau lebih mudah menghambur-hamburkan uang untuk mendapatkan kepuasan, sehingga responden lebih banyak membeli produk tersebut untuk memenuhi kepuasan mengkonsumsi produk tersebut. Sebaliknya jika responden berpenghasilan lebih sedikit cenderung memiliki kepribadian yang lebih terkendali sehingga para responden tidak hanya memikirkan kepuasan semata. Sulistyawati (2004) menyatakan bahwa tingkat pendapatan juga mempunyai pengaruh terhadap keputusan pembelian konsumen. Pendapatan yang dimaksud disini adalah pendapatan individu konsumen. Pendapatan menjadi hal yang sangat penting karena keputusan pem- 
belian erat kaitannya dengan tingkat pendapatan seseorang dan pengeluaran seseorang. Semakin tinggi tingkat pendapatan seseorang cenderung semakin tinggi pula pengeluaran yang dilakukan.

Faktor karakteristik konsumen memiliki persentase varian sebesar $4,708 \%$ dan merupakan urutan kedelapan yang dipertimbangkan oleh konsumen karena mempunyai nilai Eigen Value terbesar yaitu 1,036. Variabel demografi sudah pasti memiliki factor loading terbesar karena variabel demografi merupakan variabel satu-satunya yang diwakili faktor karakteristik konsumen yaitu sebesar 0,767 yang artinya bahwa variabel demografi memiliki korelasi yang sangat kuat terhadap faktor karakteristik konsumen.

Demografi konsumen didekati dengan variabel-variabel seperti usia, jenis kelamin, pendidikan, dan pendapatan. Responden wanita cenderung lebih senang berbelanja, mudah terpengaruh oleh emosi, dan menyukai jajan atau makanan camilan.

\section{Kesimpulan}

Sebagian besar responden yang melakukan pembelian bakso adalah perempuan, berstatus pelajar, mempunyai umur di bawah 35 tahun, pendapatan individu yang diperoleh antara Rp. 1.000.000,00 sampai Rp. 2.000.000,00 per bulan dan harga bakso Rp. 5.000,00 seporsi dapat dikategorikan terjangkau. Pola mengkonsumi bakso bukan sebagai makanan pokok tetapi sebagai kuliner, hobi, dan makanan camilan. Delapan faktor yang dipertimbangkan responden secara berurutan adalah harga, kelas sosial, kemudahan mencapai lokasi, parkir, tampilan penyajian, kepuasan, pendapatan, dan demografi.

\section{Daftar Pustaka}

Asseal, H. 1992. Consumer Behavior and Marketing Action. New York: PWS-KENT. Publishing Company, Boston.

Hermanianto, J. dan R.Y. Andayani. 2002. Studi perilaku konsumen dan identifikasi parameter bakso sapi berdasarkan preferensi konsumen di wilayah DKI Jakarta. Jurnal Teknologi dan Indutri Pangan 13(1): 1-10.

Parubak, B., A. Thoyib, dan A. Suman. 2004. Faktor faktor yang dipertimbangkan konsumen dalam pembelian kain donggala di Kotamadya Palu. Kumpulan Artikel Seminar Hasil Penelitian. Bidang Kajian Perilaku Konsumen. Program Magister Manajemen. Pascasarjana, Universitas Brawijaya. Malang. Hal. 1-12.

Sudarmiatin. 2009. Model perilaku konsumen dalam perspektif teori dan empiris pada jasa pariwisata. Jurnal Ekonomi Bisnis 14(1): 111.

Sulistyawati, E. 2004. Analisis faktor faktor yang mempengaruhi perilaku konsumen dalam keputusan pembelian produk patung kayu pada toko kerajinan di Kecamatan Sukawati, Gianyar, Bali. Kumpulan artikel Seminar Hasil Penelitian. Bidang kajian Perilaku Konsumen. Program Magister Manajemen Universitas Brawijaya Malang. Hal. 67-84.

Tedjakusuma, R., S. Hartini, dan Muryani. 2001. Analisis faktor-faktor yang mempengaruhi perilaku konsumen dalam pembelian air minum mineral di Kotamadya Surabaya. Jurnal Penelitian Dinamika Sosial 2(3): 4858.

Tarwotjo, I., S. Hartini, S. Soekirman, dan Soekarno. 1971. Komposisi Tiga Jenis Bakso. Akademi Gizi, Jakarta. 